\title{
Candida Species Adhesion to Oral Epithelium: Factors Involved and Experimental Methodology Used
}

\author{
Mariana Henriques, Joana Azeredo, and Rosário Oliveira \\ Centre of Biological Engineering, University of Minho, Braga, Portugal
}

\begin{abstract}
Due to the increasing prevalence and emergence of Non-Candida albicans Candida (NCAC) species, especially in immunosupressed patients, it is becoming urgent to deepen the current knowledge about virulence factors of these species. Adhesion of cells to epithelium is considered one of the major virulence factors of Candida species. However, relatively little is known concerning the adhesion mechanisms of NCAC species to epithelium, as well as about the factors affecting the adhesion process. This review focuses both the mechanisms that regulate the adhesion interactions and the factors involved and the description of the experimental methodology that has been used to perform the adhesion assays.
\end{abstract}

Keywords Adhesion; Candida; Species; Oral epithelium

\section{INTRODUCTION}

Oral Candidiasis is one of the most common pathologies encountered in patients with HIV infection, developing in over $80 \%$ of these individuals at some time during their illness. In non-immunocompromised patients, this infection can often be eradicated with a short course of topical or oral treatment with an azole compound. However, because of the profound and sustained immunosuppression in patients with AIDS, persistent or recurrent oral infection with Candida species is common and long courses of antifungal treatment are required if remission from infection is to be achieved and sustained (Jacobs and Nall 1997). According to Odds (1987), most people usually carry a single strain of Candida at different body sites for a long time, for instances Candida dubliniensis can be found in the oropharynx or in the upper respiratory tract (Sullivan et al. 2005) while Candida albicans is most prevalent in the palate, tongue and gingiva. However, it has been shown that a few individuals may harbour more than one strain or species of Candida at the same

Received 12 May 2006; accepted 1 June 2006.

The authors fully acknowledge FCT/Portugal grant SFRH/ BPD17549/2004 and project POCTI/BIO/42638/2001.

Address correspondence to Mariana Henriques, Department of Biological Engineering, University of Minho, Campus Gualtar, 4710-057 Braga, Portugal. E-mail: mcrh@deb.uminho.pt time, and that in hospitalized and immunocompromised patients this occurs more commonly (McCullough et al. 1996).

Although Candida species are commensal, the median reported prevalence of oral yeast carriage in the general population is $34 \%$ while in hospitalized patients it rises to $55 \%$ (MacFarlane 1990). The attributable mortality of Candida infections is as high as $38 \%$ (Wey et al. 1988).

Whether Candida simply remains as a commensal or proliferates, invading tissues and producing Candidiasis is determined by changes in the environment of the host. The commensal relationship is dependent on the maintenance of host tissue integrity with normal microbial flora as well as on an intact immune system. As long as these host conditions are maintained, mucosal Candidiasis is not observed clinically. However, a breakdown in anatomic integrity or a change in the resident microbial flora can lead to environmental conditions that are favourable for the growth of Candida spp. with potential for host invasion by the fungus. Such environmental conditions in conjunction with an imbalance of host cytokine response can lead to increased tissue colonization and fungal overload resulting in mucosal Candidiasis (Calderone 2002a). The infections produced range from the superficial to the systemic. The latter type is mainly observed in individuals with immunological deficiencies and represents an important clinical problem (Pla et al. 1996).

Among the several Candida species, Candida albicans is by far the most studied. Although, other Candida species are emerging pathogens, namely: $C$. parapsilosis, $C$. tropicalis, $C$. guilliermondi, C. glabrata, C. krusei, C. lusitaniae, C. kefir, and $C$. dubliniensis, which are now generally referred to as nonCandida albicans Candida (NCAC) species. The prevalence of these species has been changing along the years. In the 1980s, according to the studies made by Kiehn et al. (1980), C.albicans constituted $68 \%$ of isolates from sites other than blood in cancer patients, while $C$. tropicalis, $C$. parapsilosis, $C$. glabrata and $C$. krusei accounted for 12.3, 10.3, 3.0, and 1.5\% of isolates, respectively. In representative studies of fungemia in immunocompromised hosts, diabetics, neonates and surgical patients $C$. albicans again accounted for $60-80 \%$ of the isolates, while other Candida species were identified less than $20 \%$ of the time (Butler and Baker 1988). In the same decade it was also 
reported that $70-78 \%$ of the isolates were Candida albicans (Finlay 1986). Nevertheless, studies from the 1990s reported only 56-57\% of the isolates as C.albicans (Jobbins et al. 1992), revealing the emergence of NCAC species. Davies et al. (2002), assessed the presence of Candida species in oral rinses from patients with cancer and found $46 \%$ of $C$. albicans, $18 \%$ of Candida glabrata, $5 \%$ of Candida dubliniensis, and less than $5 \%$ of other non-Candida albicans Candida species. This value of approximately $50 \%$ of Candida albicans prevalence was also confirmed by Borst et al. (2003). More recently, $40 \%$ of the fungemia cases reported by Bassetti et al. (2006) were due to Candida albicans.

The most similar NCAC species to Candida albicans is Candida dubliniensis presenting a very analogous genotype and phenotype, which led to their misidentification for years. The most conclusive evidence demonstrating that Candida dubliniensis was distinct from other Candida species was generated by phylogenetic analysis of nucleotide sequences encoding de V3 region of the larger rRNA subunit gene (Sullivan et al. 1997). This species was only identified in 1995 (Sullivan et al. 1995) and it was primarily associated with oral carriage and infection in HIVinfected and AIDS patients. The prevalence of Candida dubliniensis in these patients indicates that due to severe immunodeficiency this organism can emerge as an opportunistic pathogen, probably from the patients' own flora. In this environment, the ability of $C$. dubliniensis to adhere strongly to oral epithelial cells may provide it with a competitive advantage over other, less adherent, NCAC species (Gilfillan et al. 1998; McCullough et al. 1995). There are some Candida dubliniensis isolates that are resistant to fluconazole and this ability may confer a further selective advantage to $C$. dubliniensis in HIV-infected individuals receiving long-term maintenance therapy for suppression of oral Candidiasis. However, this antifungal susceptibility is not as strong as it is in C. krusei and C. glabrata (Pfaller et al. 2002). The increase in Candida glabrata systemic infections is a subject of considerable concern due to the tendency of this species to rapidly develop resistance to azole antifungal agents and due to the high mortality rate associated with $C$. glabrata fungemia (Fidel et al. 1999). Although this species is second only to $C$. albicans as a cause of systemic Candidiasis, it is a pathogen of low virulence and infection is usually associated with severely debilitated patients (Komshian et al. 1989). Infections caused by Candida krusei are prevalent in patients receiving prophylactic fluconazole therapy (Rex JH et al. 2000). Some studies (Chavanet et al. 1994) described the replacement of C.albicans with $C$. krusei in the oral cavities of HIV-infected patients following azole therapy. Although $C$. krusei is inherently resistant to fluconazole, some authors (Berrouane et al. 1996; Kao et al. 1999) have also noticed reduced susceptibility to other antifungal drugs among isolates of $C$. krusei, leading to the fact that $C$. krusei is a multidrug-resistant pathogen. The other two Candida species better known are $C$. parapsilosis and $C$. tropicalis: the former is the second most frequently recovered from blood culture and the latter the second most virulent.
Candida parapsilosis is commonly recovered from human skin and can adhere strongly to the surfaces of intravascular catheters and prosthetic devices (De Bernardis et al. 1999; Levin et al. 1998). In contrast to the other NCAC species already described here, $C$. parapsilosis is generally susceptible to all of the major antifungal drugs, as well as $C$. tropicalis. The latter has been reported as the NCAC species most commonly recovered from blood culture in patients with cancer (Komshian et al. 1989; Wingard 1995). However, it has been shown that during the recent shifts in the epidemiology of Candidiasis, $C$. tropicalis has now been superseded by $C$. glabrata and $C$. parapsilosis in overall importance (Pfaller et al. 2000; Berrouane et al. 1999).

In vitro studies have demonstrated that NCAC species generally are less adherent to buccal epithelial and vascular endothelial cells, secreting less proteinases than $C$. albicans, which may account for their reduced virulence (Hube 1996; King et al. 1980). C. albicans is undoubtedly the most virulent Candida species, followed by $C$. tropicalis (Ghannoum and Abu-Elteen 1991). This virulence of $C$. tropicalis may be due to its greater ability to adhere to epithelial cells and its ability to secrete moderate amounts of proteinase relatively to the other NCAC species (King et al. 1980; Zaugg et al. 2001). C. parapsilosis seems to be less virulent (De Bernardis et al. 1999) followed by the other NCAC species.

In order to proliferate in the oral cavity, yeast cells must adhere to the oral surfaces otherwise they are washed out by the salivary flows. So, one of the most important factors of virulence of Candida species is their ability to adhere using a variety of mechanisms, permitting the yeast to anchor at a site and the process of tissue colonization to commence (Cotter and Kavanagh 2000). After colonizing the host's mucosal surfaces, Candida species may then invade beneath the mucosal barrier into the vascular space, where continued replication causes hematogenously disseminated disease (Hostetter 1994).

Although the importance of NCAC species is everyday more evident, there are still only few studies concerning them. For instance, in the recent major Candida meeting, "8th ASM meeting on Candida and Candidiasis, 2006," only $16 \%$ of the work presented concerned these species.

\section{YEAST-EPITHELIAL CELL INTERACTIONS}

The first observation that adherence of $C$. albicans could be important for virulence was provided by King et al. (1980).

Adherence to host tissue cannot be explained by one single specific event, because it can be ruled by a combination of specific and non-specific interactions.

\section{Specific Interactions}

The components of the organism that promote host recognition and colonization are referred to as adhesins. According to Calderone and Fonzi (2001), an adhesin can be defined as a biomolecule that promotes adhesion of microbial cells to host cells or host-cell ligands. Host cells have some components that 
are recognized by Candida adhesins. These components can be biomolecules of different classes, namely, carbohydrates or proteins. The adhesins of Candida albicans are usually of polysaccharide or glycoprotein nature (Calderone and Gow 2002). Several types of yeast adhesins, cell receptors and genes, as well as secreted aspartyl proteinases (SAP) are involved in the yeast-cell specific interactions.

\section{Epithelial Cell Factors}

(i) Fibronectin. Fibronectin was one of the first molecules to be suggested as a ligand recognized by C. albicans adhesins (Skerl et al. 1984). Fibronectin is a plasma and interstitial tissue glycoprotein to which a number of microorganisms avidly adhere (Pendrak and Klotz 1995). This protein ranges in mass from 37 to $120 \mathrm{kDa}$. Santoni et al. (1994) found that adhesion of C. albicans blastospores to immobilized fibronectin containing the RGD tripeptide was inhibited by monoclonal antibodies and by the GRGDSP peptide from fibronectin. One year later the same authors (Santoni et al. 1995) described that a monoclonal antibody against placental $\alpha 5 \beta 1$ and two polyclonal antibodies recognizing vertebrate fibronectin receptors also bound to NCAC species. These studies provided evidence for fibronectin receptors in $C$. albicans and $C$. tropicalis that resemble the vertebrate integrins $\alpha 5$ and $\beta 1$. In disseminated Candidiasis, the fibronectin adhesin may be responsible for the adherence of the microorganism to intravascular and vascular structures such as endothelial cells or subendothelial extracellular matrix (Pendrak and Klotz 1995). The presence of fibronectin as a target protein for epithelial attachment of Candida tropicalis was also confirmed by Bendel et al. (1993).

(ii) Integrins. An integrin or integrin receptor is an integral membrane protein in the plasma membrane of cells. On vertebrate cells, integrins serve a multiplicity of functions from adhesion to morphogenesis. Candida proteins exhibiting antigenic and functional similarities to human complement receptors 3 and 4 (CR3 and CR4) are known as integrin analogs because of the placement of CR3 and CR4 within the integrin supergene family (Hostetter 1994).

Included in the $\mathrm{C} 3$ ligands are $\mathrm{C} 3 \mathrm{~b}, \mathrm{C} 3 \mathrm{~d}$, and $\mathrm{iC} 3 \mathrm{~b}$ that are ligands for CR1, CR2, respectively, and CR4 (for the last two). The $\mathrm{iC} 3 \mathrm{~b}$ receptors are present on the surface of $C$. albicans, and these share homology with a subunit of the neutrophilic $\mathrm{iC} 3 \mathrm{~b}$ receptor (Lee et al. 1997) and it is proposed that a number of fungal proteins mediate $C$. albicans adherence to $\mathrm{iC} 3 \mathrm{~b}$ receptors (CR3-like). The presence of a receptor for $\mathrm{iC} 3 \mathrm{~b}$ on the surface of $C$. albicans allowed noncovalent binding of this protein, thereby suggesting that $C$. albicans was using this form of molecular mimicry to elude phagocytosis (Hostetter 1999).

The presence of a receptor for $\mathrm{C} 3 \mathrm{~d}$ on $C$. albicans and $C$. stellatoidea was initially described by Heidenreich and Dietrich (1985) and later confirmed by Edwards et al. (1986). While Heidenreich and Dietrich (1985) observed this receptor and a receptor for $\mathrm{iC} 3 \mathrm{~b}$ on both yeasts and hyphal forms, Edwards et al. (1986) only detected it on hyphal forms. Calderone et al.
(1988) identified, in extracts of $C$. albicans pseudohyphae, two proteins of approximately 62 and $70 \mathrm{kDa}$ that bind the $\mathrm{C} 3 \mathrm{~d}$ fragment of $\mathrm{C} 3$. The finding of $\mathrm{C} 3$ receptors, exclusively on the more pathogenic Candida spp. is highly suggestive of their involvement in disease processes (Calderone et al. 1988).

According to Bendel and Hostetter (1993) epithelial adhesion of $C$. tropicalis is not significantly inhibited by $\mathrm{iC} 3 \mathrm{~b}$ and $\mathrm{iC} 3 \mathrm{~b}-$ RGD peptides, however, two peptides in the group-I-RGDQD and RGDQDATMS - were more inhibitory than the remainder.

\section{Yeast Factors}

(i) Genetic regulation. It was proposed by Staib et al. (1999) that a developmentally regulated gene (HWP1), expressed in germ-tube and hyphal forms of $C$. albicans, encodes an outer cell-wall mannoprotein that interacts with epithelial cell transglutaminase, forming a non-dissociable complex. Tsuchmori et al. (2000) demonstrated that an HWP1deficient mutant of $C$. albicans caused reduced mortality in mice, germinated less readily in the kidneys of infected mice and caused less endothelial cell damage. This confirms the role of HWP1 in adherence and virulence.

Agglutin-Like Sequence (ALS) of Candida albicans is a family of seven glycosylated proteins with homology to the $S$. cerevisae $\alpha$-agglutinin protein that is required for cell-cell recognition during mating (Calderone and Fonzi 2001). For C. albicans, both ALS1p and ALS5p appear to provide an adhesive function (Gaur et al. 1999; Fu et al. 1998). ALS genes are differentially regulated in $C$. albicans by physiologically relevant conditions such as growth medium changes (ALS1) (Hoyer et al. 1995; Hoyer 2001), morphological form (ALS3/ALS8) (Hoyer et al. 1998b; Hoyer and Hecht 2000) and stage of growth (ALS4) (Hoyer et al. 1998a). Hoyer et al. (2001) observed differences in ALS gene expression by $C$. albicans and $C$. dubliniensis. In $C$. albicans, it is typical to observe one or two ALS genes concurrently expressed under a specific in vitro growth condition. By contrast, more ALS cross-hybridizing messages were observed on $C$. dubliniensis northern blots. Hoyer et al. (2001) demonstrated that ALS gene families are found in $C$. dubliniensis and $C$. tropicalis, although they are not identical to that in C. albicans. Studies of ALS genes in $C$. dubliniensis suggest differences in regulation of the gene family and in production of cell wall proteins.

Studies of the ALS family revealed many significant parallels to the $C$. albicans SAP family (Hoyer et al. 2001; Hube et al. 1994; Hube 1996). Both families appear to have similar numbers of genes in C. albicans. Genes in each family are differentially regulated by similar mechanisms and ALS and SAP are largely co-localized on the same $C$. albicans chromosomes. This colocalization trend continues in species such as $C$. dubliniensis and $C$. tropicalis. The number of ALS genes is roughly equal to the number of SAP genes in these species (Hoyer 2001).

In $C$. glabrata, adherence is mediated largely by the EPA (Epithelial Adhesion) family of genes, which, like HWP1 or the ALS genes encode GPI-anchored cell wall proteins. Epal is a 
lectin that binds to $\mathrm{N}$-acetyllactosamine-containing glycoconjugates (Kaur et al. 2005; Cormack et al. 1999).

The Candida glabrata genome encodes many EPA-related genes. Despite the large number of $E P A$ genes, deletion of just $E P A 1$ reduces adherence in vitro to background levels because the other EPA genes are expressed at low levels when grown in laboratory broth (Castano et al. 2005; De Las Penas et al. 2003). The deletion of the EPAl gene reduces adherence by 95\% (Cormack et al. 1999).

(ii) SAP. Secreted Aspartyl Proteinases (SAP) also appear to contribute to adhesion of Candida albicans to buccal epithelial cells (BEC) and other substrates (Watts et al. 1998; Cannon and Chaffin 1999). SAP were first described by Staib in 1965 (Staib 1965) and originally designated as CAP (Candida aspartyl protease). SAP 1 was described by Hube et al. (1991) and SAP2 described by Wright et al. (1992). According to White et al. (1993), there are at least three SAPs. The three proteinases isoenzymes described differ in the primary sequence, $\mathrm{pI}$ and pattern of expression and are products of three separate genetic loci. These differences suggested that the different proteinases may have unique roles in the interaction between Candida and its host. Some more SAP were identified later, including SAP4 (Miyasaki et al. 1994), SAP5, SAP6 and SAP7 (Monod et al. 1994), SAP8 (Morrison et al. 1993), and SAP9 (Monod et al. 1998).

White and Agabian (1995) studied the influence of growing conditions and cell type in the production of SAP. In their study, they defined the culture conditions that control the levels of SAP mRNAs and Sap proteins, and they indicate that both yeast/hyphal transition and phenotypic switching can determine which of the Sap isoenzymes is produced.

Some authors (Hube et al. 1997; Sanglard et al. 1997) found that in guinea pig and murine models of invasive disease, deletions in SAP1-6 attenuate virulence. Thus, it would appear that SAP1-6 is required for invasive disease. An in vitro model of human oral Candidiasis has been used to follow the temporal transcription of SAP1-8. SAP4 and SAP5 were never detected and SAP1 and SAP3 were expressed within $42 \mathrm{~h}$ of tissue postinfection, followed by SAP6 and SAP2 and SAP8 (Calderone and Fonzi 2001).

Genes encoding aspartyl proteinase have been cloned in $C$. albicans and C. tropicalis (Hube et al. 2006; Togni et al. 1991; Wright et al. 1992). Borg and Ruchel (1988) found that evidence implicating a role for aspartyl proteinase includes the demonstration of the proteinase in both blastospores and invading germ tubes of $C$. albicans and C. tropicalis but not in C.parapsilosis.

\section{Non-Specific Interactions}

Besides specific interactions, there are other types of interactions, named non-specific, which can rule the adhesion phenomenon. These interactions are directly related to cell surface properties, and are mediated by hydrophobic and electrostatic forces.

Some studies in bacteria lead to the finding that hydrophobic interactions are believed to contribute to adherence by maintain- ing the fidelity of the adhesin-receptors bonds (Beachey 1981; Rosenberg and Kjelleberg 1986). In relation to yeast Candida cells, Rotrosen et al. (1986) and Hazen (1989), described that cell surface hydrophobicity (which increases at lower growth temperature) contributes to, adherence to BEC, but not as the predominant mechanism. Jones et al. (1995) also described that a decrease in hydrophobicity may contribute partially to the decrease in binding.

The influence of Candida krusei surface hydrophobicity on the adhesion to HeLa cells was compared to that of Candida albicans by Samaranayke et al. (1995). These authors found a positive correlation between cell surface hydrophobicity and adherence of $C$. krusei to HeLa cells but no such relationship was observed for $C$. albicans. Henriques (2005) also found no relationship between Candida albicans and Candida dubliniensis adhesion to HeLa cells and cell surface physico-chemical properties.

Kltotz (1994) studied the contribution of electrostatic forces to the adherence of Candida albicans to substrates and concluded that electrostatic forces although present in the process of adherence of yeast cells to some substrata, is a minor force which makes only a modest, at best, contribution to adherence.

\section{ENVIRONMENTAL FACTORS AFFECTING ADHESION Yeast Morphogenesis}

Candida albicans undergoes reversible morphological transitions between ovoid, unicellular budding cells (yeast cells or blastospores) and chains of filamentous cells. The latter cell morphism displays different degrees of filamentation, ranging from slightly elongated ovoid cells to significantly extended tube-like cells. Filamentous cells are classified either as pseudohyphae or hyphae depending on their morphology. Although the degree of elongation of pseudohyphal cells can vary considerably, from relatively short to significant extended cells, they always display constrictions at their septa between individual cellular compartments. In contrast, true hyphae and their progenitors (germ tubes) show no constrictions, having parallel walls at their septa (Calderone 2002c).

Candida albicans ability to switch from yeast to hyphal growth in response to various environmental signals is directly related with its pathogenicity (Liu 2001). Prasad (1991) studied the contribution of dimorphic growth to virulence, determining the virulence of mutants that can grow only in either the yeast or filamentous form. Although virulence is decreased for such mutants, the strains used in those studies were produced by classical genetic methods and are likely to carry multiple genetic lesions.

There are evidences suggesting that yeast-hypha morphogenesis is co-regulated with other virulence factors. For instance, SAP4-6 genes, members of a large family of secreted aspartyl proteinase genes, that promote the virulence of C. albicans (Hube et al. 1997; Brown 2002), are expressed specifically during hyphal development. Of all the Candida spp., only $C$. albicans and C. dubliniensis form both types of filamentous 
growth (Calderone and Fonzi 2001), although, some species, as $C$. glabrata, can form pseudohyphae in response to nitrogen starvation (Csank and Haynes 2000).

\section{Sugars}

One of the main causes of oral Candidiasis is the presence of great amounts of carbohydrates in the oral cavity. Pizzo et al. (1999) studied the effect of some carbohydrates on the adhesion of some Candida species to epithelial cells. Their results indicate that incubation in sucrose or glucose significantly promotes adhesion of Candida albicans to epithelial cells. This is in agreement with previous studies by Samaranayke and MacFarlane (1982). They also found that diets rich in glucose or sucrose could influence the development and outcome of oral Candidiasis by enhancing Candida albicans adhesion, as well as $C$. tropicalis and $C$. krusei. The effect of glucose can be due to the production of a mannoprotein surface layer, which is known to enhance adhesion (McCourtie and Douglas 1985). Other studies (Samaranayake et al. 1986; McCullough et al. 1996) lead also to the conclusion that glucose can promote acid production and lower the $\mathrm{pH}$, with consequent activation of acid proteinases and extracellular phospholipases, factors involved in yeasts adhesion. Other two important carbohydrates are fructose, which is present in fruits and honey and is used as a sucrose substitute in confectionery and maltose that is found in starchy foods accumulating on dental and prosthetic surfaces. These two carbohydrates, as well as glucose and sucrose, also enhance Candida adhesion to epithelium (Pizzo et al. 1999), although the extent of adhesion appeared to be lower in the presence of maltose. Besides the differences in the carbohydrates present in the growth media, adhesion is also dependent on the type of culture conditions (broth or solid media).

\section{Temperature}

Temperature of growth is known to affect cell morphology of dimorphic fungi including C. albicans (Ghannoum and AbuElteen 1991), thus affecting yeast cell-surface composition. The adhesion of $C$. albicans to BEC can be significantly modified by the temperature at which cells grow. Growth at $25^{\circ} \mathrm{C}$ increases the extent of adhesion when compared to cells grown at $37^{\circ} \mathrm{C}$ (Kennedy and Sandin 1988). According to Kennedy and Sandin (1988), C. albicans grown on Sabouraud Agar at $37^{\circ} \mathrm{C}$ was significantly more adhesive than when grown in Sabouraud broth. Growth phase of $C$. albicans has a marked influence on its adherence ability. Stationary phase yeasts, those cultured for periods longer than $18 \mathrm{~h}$, were found to adhere to a greater degree than logarithmic-phase blastospores. However prolonged growth of the culture does not significantly enhance adherence (Calderone 2002b).

\section{Inoculum Concentration}

The inoculum concentration is determinant to the adhesion assays. There is no detectable yeast attachment at concentrations bellow $10^{4}$ yeast $\mathrm{ml}^{-1}$. In fact, $10^{7}$ yeast $\mathrm{ml}^{-1}$ is the most used inoculum concentration. It has been reported that attachment of $C$. albicans to BEC/VEC (vaginal epithelial cells) gradually increases as the ratio of yeasts to epithelial cells in incubation mixtures is raised from 10:1 to 10000:1 (Kimura and Pearsall 1978; Lee et al. 1997). Kennedy and Sandin (1988) also reported that as the number of Candida that attached to epithelial cells increased, the percentage of BEC which had attached yeasts increased as well.

\section{ASSESSMENT OF "IN VITRO" ADHESION}

The study of Candida adhesion to epithelium involves three major steps, the preparation of the epithelial cells, the adhesion assay and the quantification of the adhesion extent. Table 1 presents a summary of the Candida species, epithelial cells origin, adhesion assays, and adhesion quantification methods used by different authors.

\section{Adhesion Assays}

Yeast adherence to epithelial cells varies considerably with the origin of the epithelium. The most used sources of epithelium are exfoliated samples like BEC. The method of BEC preparation was developed in 1978 by Kimura and Pearsall (1978) and is still being used today (McCarron et al. 2004) by most of the authors (see Table 1). Accordingly, BEC are obtained by gently rubbing the oral mucosa with sterile cotton swabs, followed by dispersion in sterile PBS. Cells are immediately used after centrifugation and washing with PBS.

The main problem is that BEC vary with the donor, the period of the day and other problems can arise, as a high number of nonviable cells, bacterial contamination and different degrees of enzymatic modifications of the cell surface (Cotter and Kavanagh 2000). These drawbacks were overcome by monolayer cultures. However, such cultures mimic neither the differentiation of cells during maturation, nor their interactions encountered in situ. A more realistic model seems to be reached with the combination of stromal equivalent and epithelial cells, commonly called organotypic cultures (Papaioannou 1998). Although this type of cells is convenient to use, invariably consists of heterogeneous mixtures of viable and non-viable cells and substantial cell-tocell variation in the number of adhered yeast is always observed. Such preparations may also vary according to the donor, the time of sampling, the extent of colonization by the normal flora and the degree of exposure to various secretions. Therefore, it is more convenient to use a uniform cell population obtained by culturing epithelial cells. The most common cultured cells are HeLa (derived from cervical cancer cells taken from a woman named Henrietta Lacks) and KB (derived from an epidermal carcinoma of the mouth).

Recently, Schaller et al. (1998) used a model for reconstituted human oral epithelium (RHOE), maintained as multilayer natural cell cultures. It has been used as a satisfactory model for experimental Candidiasis (Jayatilake et al. 2005). 
TABLE 1

Several parameters used in Candida adhesion to epithelium, including the source of epithelial cells, the Candida species adhered to that cells, the adhesion assay performed and the method used to quantify the adhered Candida and respective references

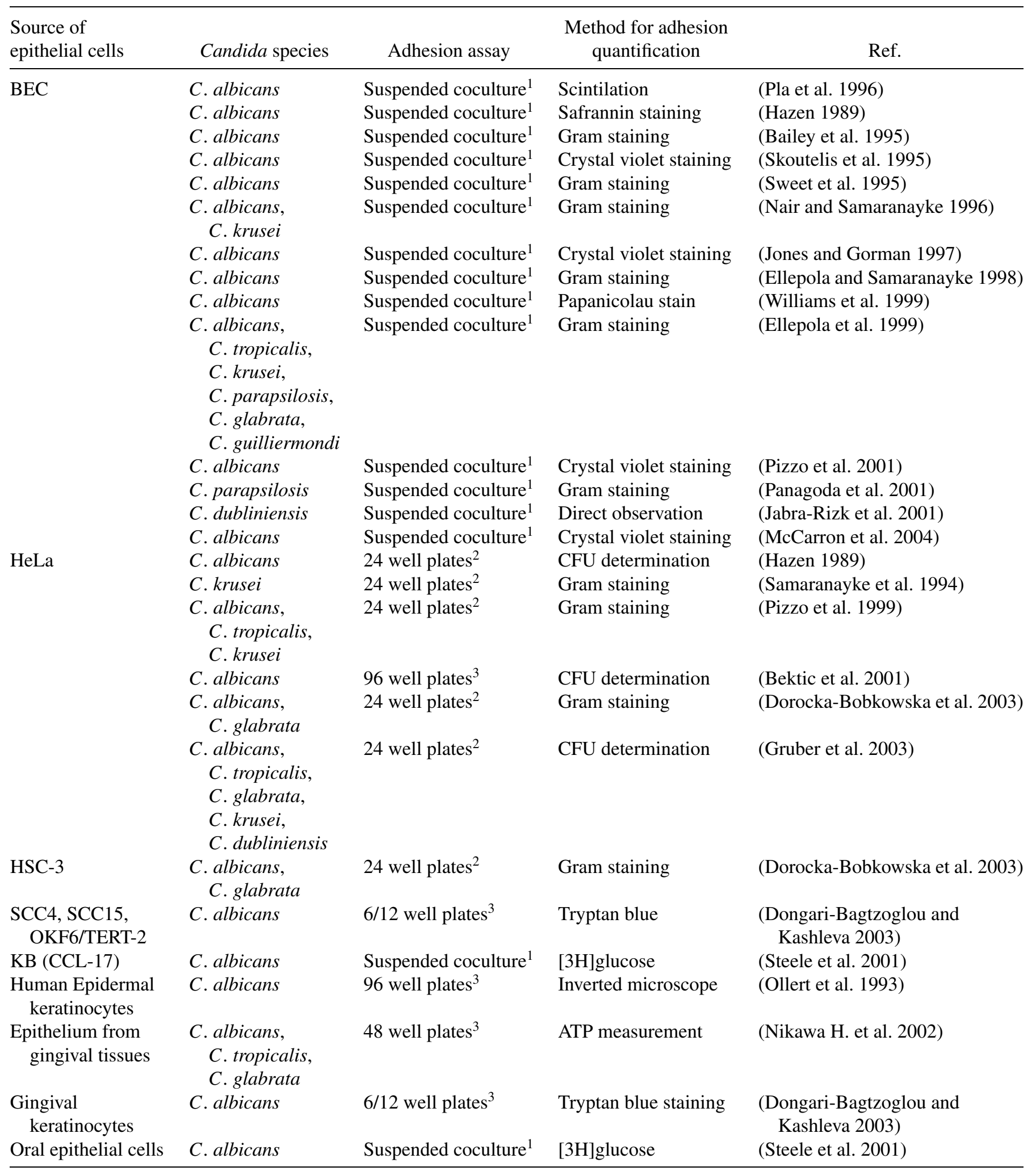

${ }^{1}$ Epithelium and yeast cells adhering in suspension.

${ }^{2}$ Epithelium adhered to glass immersed on the well plates.

${ }^{3}$ Epithelium adhered to the bottom well plates. 
According to Jayatilake et al. (2005), the advantages of this model are: its multilayer structure closely resembling the oral epithelium, the ability to artificially reproduce the internal milieu of the oral cavity and its ready off-the-shelf use for timelimited experiments. Schaller et al. (1998) showed that, histologically, RHOE resembles the normal human oral epithelium and the pathological changes that accompany Candidal invasion are akin to human disease.

\section{Quantification Methods}

The attachment of Candida albicans to buccal cells from rats was first measured by Liljemark and Gibbons (1973). A few years later Kimura and Parsall (1978) proposed a method for the study of Candida adhesion to BEC. This assay included the mix of equal amounts of BEC cells and yeast cells and incubation for $1 \mathrm{~h}$ at $37^{\circ} \mathrm{C}$. After adhesion, cells were filtered and the filters were stained and the number of Candida adhered per 100 BEC was enumerated. After several modifications, Kennedy (1990) proposed a standardization of that method, allowing uniformity of the results obtained by different researchers. Although this method is still being used (Table 1), Samaranayke and MacFarlane (1981) described a new method in 1981 for studying adhesion to epithelium that includes the adhesion of epithelial cells to the bottom of the wells of tissue culture well plates or to glass coupons (inserted on the wells) prior to the addition of microbial cells. In this method, mammalian cells must be adherent to the supporting surface.

Among the methods used to enumerate yeast cells adhered to epithelium are: the visual counting, using light, fluorescence, and electron scanning or transmission microscopy and the Coulter counting of the radiolabelled yeast. The visual method allows to follow the adhesion to individual epithelial cells but is a very time consuming technique. The radiolabelling method seems to offer an attractive alternative in some situations, although it should always be remembered that leachable isotopes can produce misleading results.

The quantification of the adhesion extent varies with the type of epithelial cells used and consequently with the adhesion assay performed (Table 1). When yeast cells adhere in suspended cocultures with epithelial cells usually a direct microscopic method is used and the percentage of epithelial cells with adhered Candida is determined. Both gram staining and CFU determination are applied to cells grown in well plates. In the first case cells are observed under the microscope and the number of Candida is determined per $\mathrm{mm}^{2}$. More recently a method involving ATP measurement was proposed (Nikawa et al. 2002). The authors developed an in vitro assay technique to extract cellular and fungal ATP separately, allowing a quantitative evaluation of the adhesion of Candida to monolayers of epithelial cells.

\section{CONCLUSIONS}

The large range of host tissues that can be colonized and infected by Candida species suggests that these organisms possess a large number of adhesive surface factors, very few of which have actually been characterized or their role is not yet well understood. Another point worth noting is that adhesion assays have been performed with a limited number of strains of each species and it is already well established that adhesion is strain dependent. Therefore, in order to deepen the understanding of the adhesion phenomenon, the studies should be conducted with different clinical isolates of Candida species and using different types of epithelium.

The prevalence of non-Candida albicans Candida (NCAC) species is emerging today. In opposition to Candida albicans, only few yeast-cell interaction mechanisms were found and described for NCAC species. So, as adhesion is considered one of the most relevant Candida virulence factors, it is becoming increasingly more important to understand the mechanisms that are involved and their role in the adhesion process of each NCAC species.

Different methodologies have been used to perform adhesion assays and to quantify the extent of adhesion. Consequently, it is difficult to meaningfully compare the results reported in literature because different cells and culture conditions were used in each case. Therefore, it is of utmost importance to standardize the methodologies used to assess yeast-epithelium adhesion.

\section{REFERENCES}

Bailey, A., Wadsworth, E., and Calderone, R.A. 1995. Adherence of Candida albicans to human buccal epithelial cells: host induced protein synthesis and signaling events. Infect. Immun. 63:569-572.

Bassetti, M., Righi, E., Costa, A., Fasce, R., Molinari, M.P., Rosso, R., Bobbio, P.F., and Viscoli, C. 2006. Epidemiological trends in nosocomial candidemia in intensive care. BMC Infect. Dis. 6:21.

Beachey, E.H. 1981. Bacterial adherence: adhesion-receptor interactions mediating the attachment of bacteria to mucosal surface. J. Infect. Dis. 143:325-345.

Bektic, J., Lell, C.R., Fuchs, A., Stoiber, H., Speth, C., Lass-Florl, C., Zepelin, M.B., Dierich, M.P., and Wurzner, R. 2001. HIV protease inhibitors attenuate adherence of Candida albicans to epithelial cells in vitro. FEMS Immunol. Med. Microbiol. 31:65-71.

Bendel, C.M. and Hostetter, M.K. 1993. Distinct mechanisms of epithelial adhesion for Candida albicans and Candida tropicalis. J. Clin. Invest. 92:1840 1849 .

Berrouane, Y.F., Hollis, R.J., and Pfaller, M.A. 1996. Strain variation among and antifungal susceptibilities of isolates of Candida krusei. J. Clin. Microbiol. 34:1856-1858.

Berrouane, Y.F., Herwaldt, L.A., and Pfaller, M.A. 1999. Trends in antifungal use and epidemiology of nosocomial yeast infections in a university hospital. J. Clin. Microbiol. 37:531-537.

Borg, M., and Ruchel, R. 1988. Expression of extracellular acid proteinase by proteolytic Candida spp. during experimental infection of oral mucosa. Infect. Immun. 56:626-631.

Borst, A., Theelen, B., Reinders, E., Boekhout, T., Fluit, A.C., and Savelkoul, P. 2003. Use of amplified fragment length polymorphism analysis to identify medically important Candida spp., including C. dubliniensis. J. Clin. Microbiol. 41:1357-1362.

Brown, A.J.P. 2002. Morphogenic signaling pathways in Candida albicans, p. 95-106. In Calderone, R.A. (ed.), Candida and Candidiasis. ASM Press, Washington D.C.

Butler, K.M., and Baker, C. 1988. Candida: an increasingly important pathogen in the nursery. Pedriatr. Clin. North. Am. 35:543-563.

Calderone, R.A. 2002. Candida and Candidiasis, Washington DC. 
Calderone, R.A. 2002. Introduction and historical perspectives, p. 3-13. In Calderone, R.A. (ed.), Candida and Candidiasis. ASM Press, Washington D.C.

Calderone, R.A. 2002. Taxonomy and biology of Candida, p. 15-27. In Calderone, R.A. (ed.), Candida and Candidiasis. ASM Press, Washington D.C.

Calderone, R.A., and Fonzi, W.A. 2001. Virulence factors of Candida albicans. Trends Microbiol. 9:327-335.

Calderone, R.A., and Gow, N.A.R. 2002. Host recognition by Candida species, p. 67-86. In Calderone, R.A. (ed.), Candida and Candidiasis. ASM Press, Washington D.C.

Calderone, R.A., Linehan, L., Wadsworth, E., and Sandberg, A.L. 1988. Identification of C3d receptors on Candida albicans. Infect. Immun. 56:252-258.

Cannon, R.D., and Chaffin, W.L. 1999. Oral Colonization by Candida albicans. Crit. Rev. Oral Biol. Med. 10:359-383.

Castano, I., Pan, S.J., Zupancic, M., Hennequin, C., Dujon, B., and Cormack, B.P. 2005. Telomere length control and transcriptional regulation of subtelomeric adhesins in Candida glabrata. Mol. Microbiol. 55:1246-1258.

Chavanet, P., Lopez, J., Grappin, M., Bonnin, A., Duong, M., Waldner, A., Buisson, M., Camerlynck, P., and Portier, H. 1994. Cross-sectional study of the susceptibility of Candida isolates to antifungal drugs and in vitro-in vivo correlation in HIV-infected patients. AIDS 8:945-950.

Cormack, B.P., Ghori, N., and Falkow, S. 1999. An adhesin of the yeast pathogen Candida glabrata mediating adherence to human epithelial cells. Science 285:578-582.

Cotter, G., and Kavanagh, K. 2000. Adherence mechanisms of Candida albicans. Br.J. Biomed. Sci. 57:241-249.

Csank, C., and Haynes, K. 2000. Candida glabrata displays pseudohyphal growth. FEMS Microbiol. Lett. 189:115-120.

Davies, A.N., Brailsford, S.R., Broadley, K., and Beighton, D. 2002. Oral yeast carriage in patients with advance cancer. Oral Micriobiol. Immunol. 17:7984.

De Bernardis, F., Mondello, F., San Millan, R. Ponton, J., and Cassone, A. 1999. Biotyping and virulence properties of skin isolates of Candida parapsilosis. J. Clin. Microbiol. 37:3481-3486.

De Las Penas, A., Pan, S.J., Castano, I., Alder, J., Cregg, R., and Cormack, B.P. 2003. Virulence-related surface glycoproteins in the yeast pathogen Candida glabrata are encoded in subtelomeric clusters and subject to RAP1- and SIRdependent transcriptional silencing. Genes Dev. 17:2245-2258.

Dongari-Bagtzoglou, A., and Kashleva, H. 2003. Candida albicans triggers interleukin-8 secretion by oral epithelial cells. Microb. Pathog. 34:169-177.

Dorocka-Bobkowska, B., Konopka, K., and Duzgunes, N. 2003. Influence of antifungal polyenes on the adhesion of Candida albicans and Candida glabarata to human epithelial cells in vitro. Arch. Oral Biol. 48:805-815.

Edwards, J.E., Jr., Gaither, T.A., O’Shea, J.J., Rotrosen, D., Lawley, T.J., Wright, S.A., Frank, M.M., and Green, I. 1986. Expression of specific binding sites on Candida with functional and antigenic characteristics of human complement receptors. J. Immunol. 137:3577-3583.

Ellepola, A.N.B., Panagoda, G.J., and Samaranayke, L.P. 1999. Adhesion of oral Candida species to human buccal epithelial cells following brief exposure to nystatin. Oral Microbiol. Immunol. 14:358-363.

Ellepola, A.N.B., and Samaranayke, L.P. 1998. The effect of limited exposure to antimycotics on the relative cell-surface hydrophobicity and the adhesion of oral Candida albicans to buccal epithelial cells. Arch. Oral Biol. 43:879-887.

Fidel, P.L., Jr., Vazquez, J.A., and Sobel, J.D. 1999. Candida glabrata: Review of epidemiology, pathogenesis, and clinical disease with comparison to C. albicans. Clin. Microbiol. Rev. 12:80-96.

Finlay, I.G. 1986. Oral symptoms and Candida in the terminal ill. Br. Med. J. 292:591-593.

Fu, Y., Rieg, G., Fonzi, W.A., Belanger, P.H., Edwards, J.E., Jr., and Filler, S.G. 1998. Expression of the Candida albicans gene ALS1 in Saccharomyces cerevisiae induces adherence to endothelial and epithelial cells. Infect. Immun. 66:1783-1786.

Gaur, N.K., Klotz, S.A., and Henderson, R.L. 1999. Overexpression of the Candida albicans ALA1 gene in Saccharomyces cerevisiae results in aggregation following attachment of yeast cells to extracellular matrix proteins, adherence properties similar to those of Candida albicans. Infect. Immun. 67:60406047.

Ghannoum, M.A., and Abu-Elteen, K. 1991. Adherence of Candida albicans: influencing factors and mechanism(s), p. 145-163. In Prasad, R. (ed.), Candida albicans. Springer-Verlag, Berlin.

Gilfillan, G.D., Sullivan, D.J., Haynes, K., Parkinson, T., Coleman, D.C., and Gow, N.A.R. 1998. Candida dubliniensis: phylogeny and putative virulence factors. Microbiol. 144:829-838.

Gruber, A., Lell, C.P., Spruth, M., Lass-Florl, C., Speth, C., Stoiber, H., Hube, B., Coleman, D.C., Polonelli, L., Dierich, M.P., and Wurzner, R. 2003. HIV-1 and its transmembrane protein gp41 bind to different Candida species modulating adhesion. FEMS Immunol. Med. Microbiol. 37:77-83.

Hazen, K.C. 1989. Participation of yeast cell surface hydrophobicity in adherence of Candida albicans to human epithelial cells. Infect. Immun. 57:18941900.

Heidenreich, F., and Dierich, M.P. 1985. Candida albicans and Candida stellatoidea, in contrast to other Candida species, bind $\mathrm{iC} 3 \mathrm{~b}$ and $\mathrm{C} 3 \mathrm{~d}$ but not $\mathrm{C} 3 \mathrm{~b}$. Infect. Immun. 50:598-600.

Henriques, M. 2005. Candida dubliniensis versus Candida albicans: adhesion and biofilm formation. $\mathrm{PhD}$, University of Minho.

Hostetter, M.K. 1994. Adhesins and ligands involved in the interaction of Candida spp. with epithelial and endothelial surfaces. Clin. Microbiol. Rev. 7:2942.

Hostetter, M.K. 1999. Integrin-like Proteins in Candida spp. and other microorganisms. Fungal Genet. Biol. 28:135-145.

Hoyer, L.L., Fundyga, R., Hecht, J., Kapteyn, J.C., Klis, F.M., and Arnold, J. 2001. Characterization of Agglutin-like sequence genes from non-albicans Candida and phylogenetic analysis of the ALS family. Genetics 157:15551567.

Hoyer, L.L., and Hecht, J.E. 2000. The ALS6 and ALS7 genes of Candida albicans. Yeast 16:847-855.

Hoyer, L.L., Scherer, S., Shatzman, A.R., and Livi, G.P. 1995. Candida albicans ALS1: domains related to a Saccharomyces cerevisiae sexual agglutinin separated by a repeating motif. Mol. Microbiol. 15:39-54.

Hoyer, L.L., Payne, T.L., and Hecht, J.E. 1998. Identification of Candida albicans ALS2 and ALS4 and localization of Als proteins to the fungal cell surface. J. Bacteriol. 180:5334-5343.

Hoyer, L.L., Payne, T.L., Bell, M., Myers, A.M., and Scherer, S. 1998. Candida albicans ALS3 and insights into the nature of the ALS gene family. Curr. Genet. 33:451-459.

Hoyer, L.L. 2001. The ALS gene family of Candida albicans. Trends Microbiol. 9:176-180.

Hube, B. 1996. Candida albicans secreted aspartyl proteinases. Curr. Top. Med. Mycol. 7:55-69.

Hube, B., Monod, M., Schofield, D.A., Brown, A.J., and Gow, N.A. 1994. Expression of seven members of the gene family encoding secretory aspartyl proteinases in Candida albicans. Mol. Microbiol. 14:87-99.

Hube, B., Turver, C.J., Odds, F.C., Eiffert, H., Boulnois, G.J., Kochel, H., and Ruchel, R. 1991. Sequence of the Candida albicans gene encoding the secretory aspartate proteinase. J. Med. Vet. Mycol. 29:129-132.

Hube, B., Sanglard, D., Odds, F.C., Hess, D., Monod, M., Schafer, W., Brown, A.J.P., and Gow, N.A.R. 1997. Gene disruption of each of the secretory aspartyl proteinase genes SAP1, SAP2 and SAP3 in Candida albicans attenuates virulence. Infect. Immun. 65:3529-3538.

Hube, B., Sanglard, D., Odds, F.C., Hess, D., Monod, M., Schafer, W., Brown, A.J., and Gow, N.A. 1997. Disruption of each of the secreted aspartyl proteinase genes SAP1, SAP2, and SAP3 of Candida albicans attenuates virulence. Infect. Immun. 65:3529-3538.

Jabra-Rizk, M.A., Falkler, W.A., Merz, W.G., Baqui, A.A.M.A., Kelley, J.I., and Meiller, T.F. 2001. Cell surface hydrophobicity-associated adherence of Candida dubliniensis to human buccal epithelial cells. Ver. Iber. Micol. 18:1722.

Jacobs, P.H., and Nall, L. 1997. Fungal disease. Biology, Immunology and diagnosis. Marcel Dekker, New York. 
Jayatilake, J.A., Samaranayke, Y.H., and Samaranayke, L.P. 2005. An ultrasutructural and cytochemical study of candidal invasion of reconstituted human oral epithelium. J. Oral. Pathol. Med. 34:240-246.

Jobbins, J., Bagg, J., Parsons, K., Finlay, I.G., Addy, M., and Newcombe, R.G. 1992. Oral cariage of yeasts, coliforms and staphylcocci in patients with advanced malignant disease. J. Oral. Pathol. Med. 21:305-308.

Jones, D.S., and Gorman, S.P. 1997. Characterisation of microbial adherence to epithelial cells following biocide treatment by analysis of area under the frequency distribution curve. European J. Pharm. Sci. 5:49.

Jones, D.S., Schep, L.J., and Shepherd, M.G. 1995. The Effect of Cetylpyridinium Chloride (CPC) on the cell surface hydrophobicity and adherence of Candida albicans to human Buccal Epithelial Cells in vitro. Pharm. Res. 12:1896-1900.

Kao, A.S., Brandt, M.E., Pruitt, W.R., Conn, L.A., Perkins, B.A., Stephens, D.S., Baughman, W.S., Reingold, A.L., Rothrock, G.A., Pfaller, M.A., Pinner, R.W., and Hajjeh, R.A. 1999. The epidemiology of candidemia in two United States cities: results of a population-based active surveillance. Clin. Infect. Dis. 29:1164-1170.

Kaur, R., Domergue, R., Zupancic, M.L., and Cormack, B.P. 2005. A yeast by any other name: Candida glabrata and its interaction with the host. Curr. Opin. Microbiol. 8:378-384.

Kennedy, M.J. 1990. Models for studying the role of fungal attachment in colonization and pathogenesis. Mycopathologia 109:123-137.

Kennedy, M.J., and Sandin, R.L. 1988. Influence of growth conditions on Candida albicans adhesion, hydrophobicity and cell wall ultrastructure. J. Med. Vet. Mycol. 26:79-92.

Kiehn, T.E., Edwards, F.F., and Armstrong, D. 1980. The prevalence of yeasts in clinical specimens from cancer patients. AClin m.J. Pathol. 73:518-521.

Kimura, L.H., and Pearsall, N.N. 1978. Adherence of Candida albicans to human buccal epithelial cells. Infect. Immun. 21:64-68.

King, R.D., Lee, J.C., and Morris, A.L. 1980. Adherence of Candida albicans and other Candida species to mucosal epithelial cells. Infect. Immun. 27:667674.

Klotz, S.A. 1994. The contribution of electrostatic forces to the process of adherence of Candida albicans yeast cells to substrates. FEMS Microbiol. Lett. 120:257-262.

Komshian, S.V., Uwaydah, A.K., Sobel, J.D., and Crane, L.R. 1989. Fungemia caused by Candida species and Torulopsis glabrata in the hospitalized patient: frequency, characteristics, and evaluation of factors influencing outcome. Rev. Infect. Dis. 11:379-390.

Lee, K.H., Yoon, M.S., and Chun, W.H. 1997. The effects of monoclonal antibodies against $\mathrm{iC} 3 \mathrm{~b}$ receptors in mice with experimentally induced disseminated candidiasis. Immunol. 92:104-110.

Levin, A.S., Costa, S.F., Mussi, N.S., Basso, M., Sinto, S.I., Machado, C., Geiger, D.C., Villares, M.C.B., Schreiber, A.Z., Barone, A.A., and Branchini, M.L.M. 1998. Candida parapsilosis fungemia associated with implantable and semiimplantable central venous catheters and the hands of healthcare workers. Diagn. Microbiol. Infect. Dis. 30:243-249.

Liljemark, W.F., and Gibbons, R.J. 1973. Suppression of Candida albicans by human streptococci in gnotobiotic mice. Infect. Immun. 8:846.

Liu, H. 2001. Transcriptional control of dimorphism in Candida albicans. Curr. Opin. Microbiol. 4:728-735.

MacFarlane, T.W. 1990. Ecology and epidemiology of Candida. In Samaranayke, L.P. and MacFarlane, T.W (ed.), Oral Candidosis. Wright, London, p. 21-46.

McCarron, P.A., Donnelly, R.F., Canning, P.E., McGovern, J.G., and Jones, D.S. 2004. Bioadhesive, non-drug-loaded nanoparticles as modulators of candidal adherence to buccal epithelial cells: a potentially novel prophylaxis for candidosis. Biomaterials 25:2399-2407.

McCourtie, J., and Douglas, J. 1985. Extracellular polymer of Candida albicans: isolation, analysis and role in adhesion. J. Gen. Microbiol. 131:495-503.

McCullough, M.J., Ross, B.C., and Reade, P.C. 1995. Characterization of genetically distinct subgroup of Candida albicans strains isolated from oral cavities of patients infected with Human Immunodeficiency Virus. J. Clin. Microbiol. 33:696-700.
McCullough, M.J., Ross, B.C., and Reade, P.C. 1996. Candida albicans: a review of its history, taxonomy, epidomiology, virulence attributes, and methods of strain differentiation. Int.J. Oral Maxillofac. Surg. 25:137-144.

Miyasaki, S.H., White, T.C., and Agabian, N. 1994. A fourth secreted aspartyl proteinase gene (SAP4) and a CARE2 repetitive element are located upstream of the SAP1 gene in Candida albicans. J. Bacteriol. 176:1702-1710.

Monod, M., Togni, G., Hube, B., and Sanglard, D. 1994. Multiplicity of genes encoding secreted aspartic proteinases in Candida species. Mol. Microbiol. 13:357-368.

Monod, M., Hube, B., Hess, D., and Sanglard, D. 1998. Differential regulation of SAP8 and SAP9, which encode two new members of the secreted aspartic proteinase family in Candida albicans. Microbiology 144:2731-2737.

Morrison, C.J., Hurst, S.F., Bragg, S.L., Kuykendall, R.J., Diaz, H., Pohl, J., and Reiss, E. 1993. Heterogeneity of the purified extracellular aspartyl proteinase from Candida albicans: characterization with monoclonal antibodies and Nterminal amino acid sequence analysis. Infect. Immun. 61:2030-2036.

Nair, R.G., and Samaranayke, L.P. 1996. The effect of oral commensal bacteria on candidal adhesion to human buccal epithelial cells in vitro. J. Med. Microbiol. 45:179-185.

Nikawa, H., Egusa, H., Makihira, S., Nishiruma, M., Ishida, K., Furukawa, M., and Hamada, T. 2002. A novel technique to evaluate the adhesion of Candida species to gingival epithelial cells. Mycoses 46:384-389.

Odds, F.C. 1987. Candida infections: an overview. Crit. Rev. Microbiol. 15:1-5.

Ollert, M.W., Sohnchen, R., Korting, H.C., Ollert, U., Brautigam, S., and Brautigam, W. 1993. Mechanisms of adherence of Candida albicans to cultured human epidermal keratinocytes. Infect. Immun. 61:4560-4568.

Panagoda, G.J., Ellepola, A.N.B., and Samaranayke, L.P. 2001. Adhesion of Candida parapsilosis to epithelial and acrylic surfaces correlates with cell surface hydrophobicity. Mycoses 44:29-35.

Papaioannou, W. 1998. The adhesion of Porphyromonas gingivalis and periodontitis. PhD, Leuven University.

Pendrak, M.L., and Klotz, S.A. 1995. Adherence of Candida albicans to host cells. FEMS Microbiol. Lett. 129:103-114.

Pfaller, M.A., Messer, S.A., Gee, S., Joly, S., Pujol, C., Sullivan, D.J., Coleman, D.C., and Soll, D.R. 2002. In vitro susceptibilities of Candida dubliniensis isolates tested against the new triazoleand echinocandin antifungal agents. J. Clin. Microbiol. 37:870-872.

Pfaller, M.A., Jones, R.N., Doern, G.V., Sader, H.S., Messer, S.A., Houston, A., Coffman, S., Hollis, R.J., and The SENTRY Participant Group. 2000. Bloodstream infections due to Candida species: SENTRY antimicrobial surveillance program in North America and Latin America, 1997-1998. Antimicrob. Agents Chemother. 44:747-751.

Pizzo, G., Giuliana, G., Milici, M.E., and D'Angelo. M. 2001. Effect of antimicrobial mouthrinses on the in vitro adhesion of Candida albicans to human buccal epithelial cells. Clin. Oral Invest. 5:172-176.

Pizzo, G., Giuliana, G., Milici, M.E., and Giangreco, R. 1999. Effect of dietary carbohydrates on the in vitro epithelial adhesion of Candida albicans, Candida tropicalis and Candida krusei. New Microbiol. 23:63-71.

Pla, J., Gil, C., Monteoliva, L., Navarro-García, F., Sanchez, M., and Nombela, C. 1996. Understanding Candida albicans at the molecular level. Yeast 12:1677-1702.

Prasad, R. 1991. Candida albicans, Berlin: Springer-Verlag.

Rex, J.H., Walsh, T.J., Sobel, J.D., Filler, S.G., Pappas, P.G., Dismukes, W.E., and Edwards, J.E. 2000. Practice guidelines for the treatment of candidiasis. Infectious Diseases Society of America. Clin. Infect. Dis. 23:662-678.

Rosenberg, M., and Kjelleberg, S. 1986. Hydrophobic interactions: role in bacterial adhesion. Adv. Microb. Ecol. 9:353-393.

Rotrosen, D., Calderone, R.A., and Edwards, J.E. 1986. Adherence of Candida species to host tissues and plastic surfaces. Rev. Infect. Dis. 8:73-85.

Samaranayake, L.P., Hughes, A., Weetman, D.A., and MacFarlane, T.W. 1986. Growth and acid production of Candida species in human saliva supplemented with glucose. J. Oral Pathol. 15:251-254.

Samaranayke, L.P., and MacFarlane, T.W. 1982. The effect of dietary carbohydrates on the in-vitro adhesion of Candida albicans to epithelial cells. J. Med. Microbiol. 15:511-517. 
Samaranayke, L.P., and MacFarlane, T.W. 1981. The adhesion of the yeast Candida albicans to epithelial cells of human origin in vitro. Arch. Oral Biol. 26:815-820.

Samaranayke, Y.H., Wu, P.C., Samaranayke, L.P., and So, M. 1995. Relationship between the cell surface hydrophobicity and adherence of Candida krusei and Candida albicans to epithelial and denture acrylic surfaces. APMIS 103:707713.

Samaranayke, Y.H., Wu, P.C., Samaranayke, L.P., So, M., and Yuen, K.Y. 1994. Adhesion and colonisation of Candida krusei on host surfaces. J. Med. Microbiol. 41:250-258.

Sanglard, D., Hube, B., Monod, M., Odds, F.C., and Gow, N.A. 1997. A triple deletion of the secreted aspartyl proteinase genes SAP4, SAP5, and SAP6 of Candida albicans causes attenuated virulence. Infect. Immun. 65:35393546.

Santoni, G., Birarelli, P., Hong, L.J., Gamero, A., Djeu, J.Y., and Piccoli, M. 1995. An alpha 5 beta 1 -like integrin receptor mediates the binding of less pathogenic Candida species to fibronectin. J. Med. Microbiol. 43:360-367.

Santoni, G., Gismondi, A., Liu, J.H., Punturieri, A., Santoni, A., Frati, L., Piccoli, M., and Djeu, J.Y. 1994. Candida albicans expresses a fibronectin receptor antigenically related to alpha 5 beta 1 integrin. Microbiol. 140:2971-2979.

Schaller, M., Schafer, W., Korting, H.C., and Hube, B. 1998. Differential expression of secreted aspartyl proteinases in a model of human oral candidosis and in patient samples from the oral cavity. Mol. Microbiol. 29:605-615.

Skerl, K.G., Calderone, R.A., Segal, E., Sreevalsan, T., and Scheld, W.M. 1984. In vitro binding of Candida albicans yeast cells to human fibronectin. Can. J. Microbiol. 30:221-227.

Skoutelis, A., Lianou, P., Marselou, O., Papavalliliou, J., and Bassaris, H. 1995. Differences in adherence to buccal epithelial cells, in phagocytosis and in killing by neutrophils between human and non-human strains of Candida albicans. J. Infect. 30:17-21.

Staib, F. 1965. Serum-proteins as nitrogen source for yeastlike fungi. Sabouraudia 4:187-193.

Staib, P., Kretschmar, M., and Nichterlein, T. 1999. Host-induced stage-specific virulence gene activation in Candida albicans during infection. Mol. Microbiol. 32:533-546.

Steele, C., Leigh, J., Swoboda, R., Nishimura, H., Ozenci, H., and Fidel, P.L. 2001. Potential role for a carbohydrate moiety in anti-Candida activity of human oral epithelial cells. Infect. Immun. 69:7091-7099.

Sullivan, D.J., Haynes, K., Bille, J., Boerlin, P., Rodero, L., Lloyd, S., Henman, M., and Coleman, D.C. 1997. Widespread geographic distribution of oral Candida dubliniensis strains in human immunodeficiency virus-infected individuals. J. Clin. Microbiol. 35:960-964.

Sullivan, D.J., Westerneng, T.J., Haynes, K.A., Bennett, D.E., and Coleman, D.C. 1995. Candida dubliniensis sp. nov.: phenotypic and molecular characterisation of a novel species associated with oral candidosis in HIV-infected individuals. Microbiol. 141:1507-1521.

Sullivan, D.J., Moran, G.P., and Coleman, D.C. 2005. Candida dubliniensis: Ten years on. FEMS Microbiol. Lett. 253:9-17.

Sweet, S.P., Cookson, S., and Challacombe, S.J. 1995. Candida albicans isolates HIV-infected and AIDS patients exhibit enhanced adherence to epithelial cells. J. Med. Microbiol. 43:452-457.

Togni, G., Sanglard, D., Falchetto, R., and Monod, M. 1991. Isolation and nucleotide sequence of the extracellular acid protease gene (ACP) from the yeast Candida tropicalis. FEBS Lett. 286:181-185.

Tsuchimori, N., Sharkey, L.L., Fonzi, W.A., French, S.W., Edwards, J.E., Jr., and Filler, S.G. 2000. Reduced Virulence of HWP1-Deficient Mutants of Candida albicans and Their Interactions with Host Cells. Infect. Immun. 68:19972002.

Watts, H.J., Cheah, F.S.H., Hube, B., Sanglard, D., and Gow, N.A.R. 1998. Altered adherence in strains of Candida albicans harbouring null mutations in secreted aspartic proteinase genes. FEMS Microbiol. Lett. 159:129-135.

Wey, S.B., Mori, M., Pfaller, M.A., Woolson, R.F., and Wenzel, R. 1988. Hospital-acquired candidemia. The attributable mortality and excess length of stay. Arch. Intern. Med. 148:2642-2645.

White, T.C., and Agabian, N. 1995. Candida albicans secreted aspartyl proteinases: isoenzyme pattern is determined by cell type, and levels are determined by environmental factors. J. Bacteriol. 177:5215-5221.

White, T.C., Miyasaki, S.H., and Agabian, N. 1993. Three distinct secreted aspartyl proteinases in Candida albicans. J. Bacteriol. 175:6126-6133.

Williams, D.W., Walker, R., Lewis, M.A.O., Allison, R.T., and Potts, A.J.C. 1999. Adherence of Candida albicans to oral epithelial cells differentiated by Papanicolaou staining. J. Clin. Pathol. 52:529-531.

Wingard, J.R. 1995. Importance of Candida species other than C. albicans as pathogens in oncology patients. Clin. Infect. Dis. 20:115-125.

Wright, R.J., Carne, A., Hieber, A.D., Lamont, I.L., Emerson, G.W., and Sullivan, P.A. 1992. A second gene for a secreted aspartate proteinase in Candida albicans. J. Bacteriol. 174:7848-7853.

Zaugg, C., Borg-von Zepelin, M., Reichard, U., Sanglard, D., and Monod, M. 2001. Secreted aspartic proteinase family of Candida tropicalis. Infect. Immun. 69:405-412. 